\title{
Marketing Communication Model in Social Network Facebook
}

\author{
Herman, Winarto \\ University of Hang Tuah Surabaya, Indonesia \\ herman@hangtuah.ac.id
}

\begin{abstract}
The limited funds made small and medium enterprise attempt to do marketing communication activities by finding ways of marketing communication that does not require substantial funds.The emergence of social networking media, such as Facebook is an opportunity for small and medium enterprises (SMEs) as a cheap marketing communication media, but not many SMEs are successfully doing marketing communications with social networking media, such failure due to a lack of knowledge in utilizing the social networking media. Indonesia have many small and medium enterprises, and most of them found difficulties in marketing communication, this study was held with purpose to examine the marketing communication activity in social networking media facebook. The study used a qualitative approach, that used interview ,observation and documentation, to assess the activity of SMEs marketing communications in facebook page, the setting of the research was the SMEs who success performed marketing communication in social networking media facebook. The results of this study resulted in a model of marketing communication through social networking media facebook page, which is useful as a guide for SMEs who will do the marketing communications.
\end{abstract}

Keywords: Marketing Communication, Social Networking Media, Facebook Page, Small and Medium Enterprise

\section{Introduction}

The limited funds made small and medium enterprise attempt to do marketing communication activities by finding ways of marketing communication that does not require substantial funds. The problems faced by many small and medium enterprise are marketing their products in their business. Small entrepreneurs as an entrepreneur is always trying to find ways to solve the marketing problems. The success of an entrepreneur in the marketing activities can be categorized in entrepreneurial marketing, which is a combination of traditional marketing and behavior of an entrepreneur. The emergence of social networking media, such as Facebook is an opportunity for small and medium enterprises (SMEs) as a cheap marketing communication media. Facebook users in Indonesia has become the fourth largest users in the world with 42,272,040 users (http://allfacebook.com. May. 14, 2012). The number of users is the potency for marketers to promote the products or services globally. Facebook today has attracted many parties to use as media for online marketing communications. The emergence of facebook is interesting, because in the beginning facebook as social network media intended as a place for interaction among its members, then viewed by the people have the opportunity to be marketing communications media.

Small and medium entrepreneurs have limited marketing budgets (Zontanos and Anderson, 2004, Harris and Rae, 2009). Therefore, it can use this social networking media, as the cheapest means of marketing communication for products and services. Employers can also interact directly with customers and potential prospects who are members of Facebook. The rising of facebook user and many people use the smart mobile phone, it make them easy to get information about the product or service they need, this condition as good opportunity for small and medium entrepreneurs to communicate or inform the products or services. Herman (2011) which examined the effectiveness of the facebook page as a marketing communication media, indicating that the facebook page is very effective for disseminating presence information of a product. Facebook as a cheap and effective marketing communication media, that able to expand market reach. The study shows facebook as a cheap promotional media for small and medium enteprises who have limited funds to conduct the promotion. From the background of the problems stated above, the researcher can determine the research problem. Research problem in this study is "What effective marketing communication 
model in the social media facebook". This research needs to be done because of marketing communications with social networking media is not widely known and published in scientifically, and the results of the initial survey authors found that SMEs still do a bit of marketing communications with social networking media. In addition there are many SMEs that have not succeeded in doing marketing communications in social networking media, because they dont know the knowledge, how to do marketing communication in social networking media.

\section{Literature Review}

Rapid development of Internet technology, the rise of social media is one of the development of Internet technologies that able to facilitate two-way communication. Previously confined to one-way communication. The presence of social media make marketers have direct access to consumers and caused a bit depending on traditional media (Thackeray et al., 2008). Keenan and Shiri (2009) define social networking sites as sites that provide services to facilitate socialization or interaction for the user. while Lake (2009) defines this social networking media is a tool of low cost that combine technology and social interaction the use of words and usually based internet and mobile phones that help spread the message by way of conversation. Belch and Belch $(2009,482)$ state that social network has become a very popular destination on the internet and mobile phones, especially for young people (18-34 years) as heavy user. the popular of facebook is an opportunity for Marketers to utilize this media as a marketing communication media. The Facebook as a marketing communication media is unique in comparison with other means of marketing communication means, because of the nature of social networking media is user generated content, where on the social network user will engage directly to the web and able to affect in content creation. Different to other means of marketing communication, content will not affected because the audience is not able to involved in the process of creation the material presented by the company. Meanwhile, according to Palmer (2009) The advantages of social networking media for the company is able to involve himself with the consumers and be able to learn the needs of consumers.

Herman (2011) shows the behavior of the fan is very influential in the dissemination of information on these social networking media. Fans would always be connected (connect) to the facebook page, and has the potential to disseminate information to a friend who has.According to Belch and Belch $(2009,482)$ which makes the popular facebook is an opportunity to maintain and tracking the user's friends by sending them a message and share it in a variety of things such as ideas, images and news. There is a new name of these social sites ie "hangout sites" and its members spend a lot of time to get in touch with her friends in these social networking sites. The discussion of the user or fan in facebook caused a viral Effect (word of mouth) that give advantage to spread information because all user connected with other friends in Facebook. Thackeray et al. (2008) also stated, that the increase of facebook users and easy to disseminate information in the social networking media can increase the viral effect. Herman (2011) also stated that the behavior of the fan can affect cognitive stage (learn) from the model hierarchy, namely the effects of marketing communications (awareness and knowledge) and the Affective stage (feel) that (preferences and beliefs).

\section{Methodology}

Type of the research is exploratory research. Sources of data taken from the Facebook pages of small and medium companies which successfully do marketing communications, data collection is done by interview, observation, and documentation. Interview with the owner of the facebook page and the fans. Observation and documentation of activities and conversations carried on between the small and medium enterprises as the page owner with the fans going on the facebook page. Data analysis is the process of organizing and sorting data into patterns and categorization of data in order to obtain comprehensive information. Once the data is collected, then analyzed using qualitative analysis techniques. The process of analysis of the study include: (1). Review of all the data that has been collected through observation, documentation, and interviews; (2). Perform data reduction by abstraction, which is a summary of principal and process namely: (a). Making the units or unityzing; (b). Categorization; (c). Examination of the validity of the data; (d). Interpretation of the data. 


\section{Results and Discussion}

The results of the analysis found some marketing communication activities in facebook page, researchers found four categories of marketing communications activities, that are : advertising, sales promotion, publicity and direct marketing, which can be seen in table 1.

Table 1. Marketing Communication Activity in facebook page

\begin{tabular}{ll}
\hline No & Activity \\
\hline 1 & Advertising \\
2 & Publicity \\
3 & Sales promotion \\
4 & Direct marketing \\
\hline
\end{tabular}

Source: finding of research

Facebookpage owner stated that marketing communication activities undertaken in the facebook page is very effective. Marketing communication activities conducted in facebookpage also not costly, and makes the product is known by many people. The success of marketing communication activities are also integrated with other communication activities, the results of the analysis indicate that SMEs do a variety of other marketing communications activities such as: 1 Using a Blog and website adv free (eg. OLX, berniaga, Tokopedia etc..) 2 . Advertisements in print media 3. other social media (Twitter, Instagram, Youtube,) and messenger (Whatsapp, BBm, SMS, and Email). Activity outside of facebook marketing communications is also increasing the number of fans in facebook page.

Models in Marketing Communications Facebook page: The result of analysis and discussion of the researcher can construct a Model Marketing Communication in the facebook page, which is shown in figure 1 which is the total of all activities performed by the owner of facebook in marketing communication.

Figure 1. Model of Marketing Communication in a Facebook Page

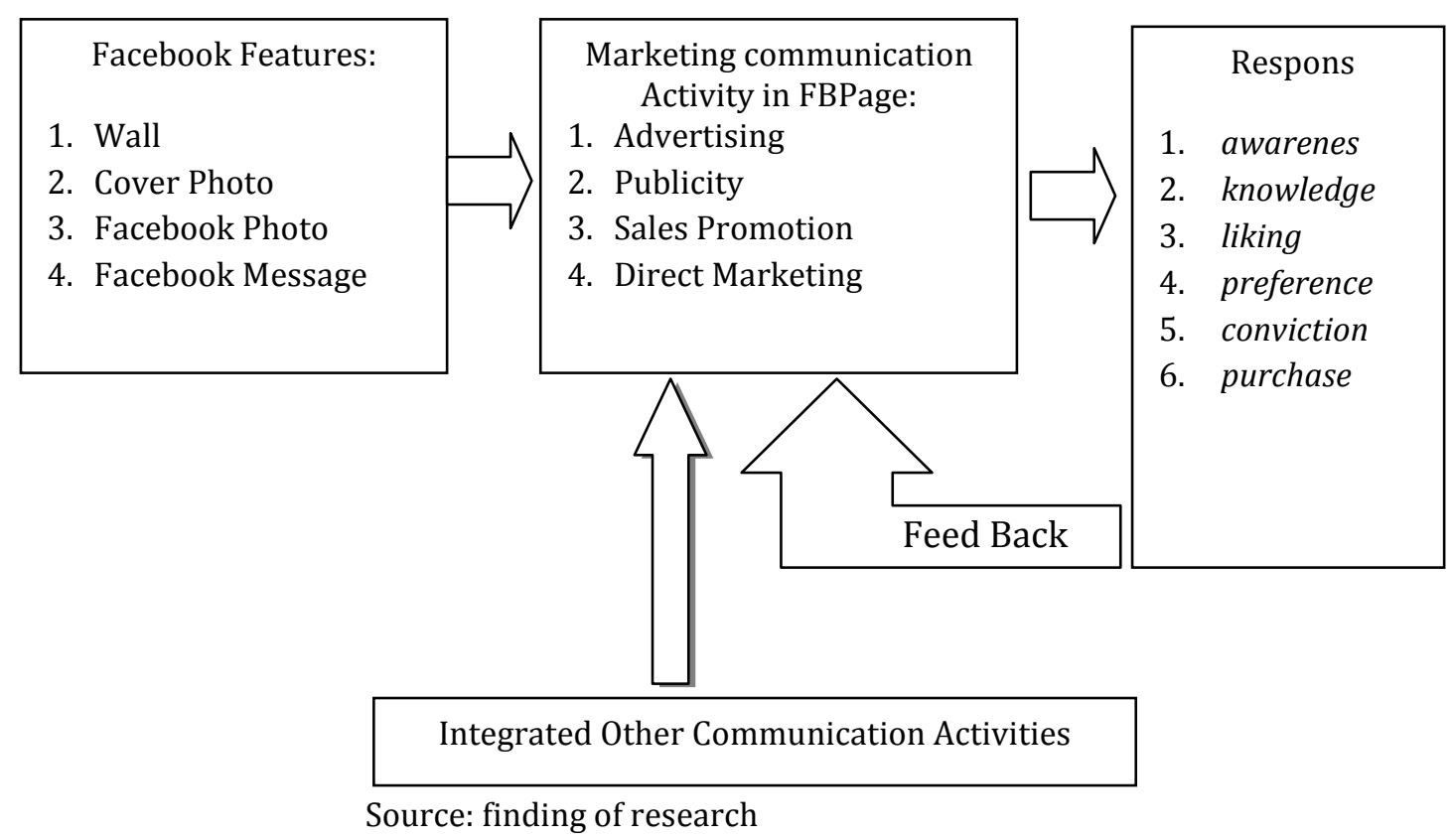

Before doing the marketing communication activities SMEs understand facebook features that can be used for marketing communications activities, to understand the features that exist in facebook can implement 
marketing communications activities such as Advertising, Publicity, Sales Promotion, and Direct Marketing. Facebook marketing communication activities within the expected response of fan. will be a feedback for SMEs as a basis to make improvements so as to satisfy the desires of fans or potential consumers. Responses and questions in facebook fan page must be answer as fast as possible because the response speed is one factor in the success of marketing communications in facebook page. Marketing communication activities outside facebookpage also be integrated with marketing communications activity in the facebookpage to improve the effectiveness of marketing communications SMEs. Audience response is the result desired by marketers in an attempt to do a marketing communications program. The model consists of a hierarchy of effects on audience response to specific marketing communications programs, namely: Awareness, Knowledge, liking, preference, belief (conviction), and Purchasing.

\section{Conclusion}

This research come to a conclusion that the marketing communication activities undertaken at the Facebookpage, the activity consists of Advertising, Publicity, Sales Promotion and Direct Marketing. Facebook page features which is used in the marketing communication activities consist of a status update, facebook Pictures, Photos Cover the front page, and Facebook messages. Marketing communication activities are most often performed is a direct marketing, which offers products to the fans by update the status and product photos. Other marketing communications activities are also integrated with marketing communication activity in facebookpage to improve the effectiveness of SME marketing communications.

\section{References}

Belch, G. E. \& Belch, M. A. (2009). Advertising and Promotion: a Integrated Marketing CommunicationPerspective. New York: McGraw-Hill Companies, Inc.

Harris, L. \& Rae, A. (2009). Social Network: the future of marketing for small business. Journal of Business Strategy, 30, 24-31

Herman. (2011). Identifikasi Tahapan Respon Fans atas Komunikasi Pemasaran Usaha Kecil dan Menegah Melalui Media Jaringan Sosial Facebook.

Keenan, A. \& Shiri, A. (2009). Sociability and Social interaction on social networking websites. Library Review, $58,438-450$.

Lake, L. (2009). Understanding the role of social media in marketing (http://www.marketing.about.com/lr/social_media_marketing/775635/1/)

Palmer, A. (2009). An experiential, social network-based approach to direct marketing. International Direct marketing journal, 3, 162-176.

Thackeray, R., Neiger, B. L., Hanson C. L. \& McKenzie, J. F. (2008). Enhancing Promotional Strategies Within Social Marketing Programs:Use of Web 2.0 Social Media. Health Promotion practice, 9, 338-343

Zontanos, G. \& Anderson, A. R. (2004). Relationships marketing and small business: an exploration of links in theory and practice. Qualitative Market Research, 7, 228-236 http://allfacebook.com/allfacebookstats-by-country_b88679. 